\title{
Comparative study of single dose versus multiple doses of antibiotic prophylaxis in caesarean delivery
}

\section{Prathima S., Savitha C., Tejeswini KK, Anitha GS*}

\begin{abstract}
Department of Obstetrics and Gynaecology, Bangalore Medical College and Research Institute, Bengaluru, Karnataka,
\end{abstract} India

Received: 27 October 2016

Accepted: 28 November 2016

*Correspondence:

Dr. Anitha GS,

E-mail: aninaik85@gmail.com

Copyright: (c) the author(s), publisher and licensee Medip Academy. This is an open-access article distributed under the terms of the Creative Commons Attribution Non-Commercial License, which permits unrestricted non-commercial use, distribution, and reproduction in any medium, provided the original work is properly cited.

\begin{abstract}
Background: Women undergoing caesarean delivery (CD) are 5 to 20 fold greater risk of infection than women of vaginal delivery group. Infectious complications after $\mathrm{CD}$ are an important and substantial cause of maternal morbidity and increase in the hospital stay and cost of treatment. The objective was to compare the efficacy of intravenous single dose, less costly cefotaxime and more expensive triple drug regimen (ceftriaxone+gentamycin+metrogyl) for 5 post operative days, for prophylaxis in caesarean delivery.

Methods: It is a prospective comparative study was undertaken on 300 subjects with 2 parallel treatment groups. Data were analyzed using Graphpad Instat 3 McIntosh software by Student's t test, Mann-Whitney U test, the Chi-squared test or fisher's exact test.

Results: Comparatively narrow spectrum low cost cefotaxime is as effective as more expensive commonly used triple drug regimen with no significant difference of infectious morbidity.

Conclusions: Less costly cefotaxime should be preferred compared to more costly triple drug regimen for prophylaxis at caesarean section.
\end{abstract}

Keywords: Antibiotics, Caesarean section, Prophylaxis

\section{INTRODUCTION}

Women undergoing caesarean delivery (CD) are 5 to 20 fold greater risk of infection than women of vaginal delivery group. Infectious complications after CD are an important and substantial cause of maternal morbidity and increase in the hospital stay and cost of treatment. ${ }^{1}$

Infectious complications following $\mathrm{CD}$ include fever, wound infection, endometritis, Urinary tract infection, and some serious complication like pelvic abscess, septic shock and septic pelvic vein thrombopheblitis. It has been proved that prophylactic single dose antibiotic is equally effective as compared to long term post-operative combination of antibiotics. $^{2}$

The most important source of microorganisms responsible for post c-section infection is the genital tract, particularly if the membranes are ruptured. Infections are commonly polymicrobial and the pathogens commonly isolated are e coli, other gram negative aerobic rods, group b streptococus, staphylococus aureus and coagulase negative staplylococci, enterococcus fecalis, gardenerella vaginalis, anaerobes and genital mycoplasma. ${ }^{3,4}$

The administration of antibiotics is not intended to sterilize tissues but to act as an adjunct to decrease the intra operative microbial load to a level which can be managed by host immune responses. The goal of antibiotic therapy is to achieve sufficient tissue level at the time of microbial contamination, and the optimal agent should be long acting, inexpensive and have a low side effect profile. ${ }^{5,6}$

However, there is considerable debate regarding the choice of antibiotics (narrow-spectrum vs. broad- 
spectrum), dose of antibiotic (single dose vs multiple dose) and the timing of administration (pre-incision or post - umbilical cord clamping).

As per the NICE clinical guidelines issued by RCOG which took into consideration, a meta-analysis of 5 RCTs found that antibiotics given before cord-clamping reduces the incidence of total maternal infectious morbidity compared to antibiotics given after cord clamping. ${ }^{7,8}$ This study is conducted to prove that single dose broad spectrum pre-incision antibiotic usage is superior and effective to be recommended for routine CD.

\section{METHODS}

The current study is prospective comparative study with 2 parallel groups, the patient screening and recruitment was carried out at obstetric department of Bowring and Lady Curzon Hospital (tertiary care teaching hospital in Bangalore).

\section{Inclusion criteria}

- Patients undergoing CD on elective or emergency basis

- Written informed consent

\section{Exclusion criteria}

- Subjects known to be hypersensitive to any of the trial drugs

- Any antibiotic treatment 2 weeks prior to surgery

- Presence of chorioamnionitis

- Diabetes

- Malnutrition

- Obesity $>85 \mathrm{kgs}$

- Immuno compromised state

- Prolonged pre-operative hospitalization

- Duration of labor $>6 \mathrm{hrs}$

- $\quad>3$ times per-vaginal examination for intra partum cases

Study drug regimens were either cefotaxime one gram single dose intravenous given one hour before the procedure (group A) or triple drug combination for 5 post-operative days (group B).

Approval for the study was taken from the institutional ethic committee. Patients were fully informed by the investigators, in their mother tongue about the aims and procedures of the study and its potential risks and benefits. Following this, written informed consent was obtained from the patients, to take part in the study.

Urinary catheter was removed $6 \mathrm{hrs}$ after operation. Oral temperature record was maintained $6^{\text {th }}$ hrly. Postoperative routine investigations like hemoglobin percentage, urine routine (urine culture if required) were sent following surgery. Presence of breast engorgement was checked in the post-operative period. If fever persisted for more than $96 \mathrm{hrs}$, blood culture was sent. In every mother, skin sutures were removed on the $7^{\text {th }}$ postoperative day for mattress sutures, suture ends were cut on $4^{\text {th }}$ post-operative day for subcuticular sutures. Wounds were inspected and uninfected mothers were discharged on the next day.

Patients enrolled in the study (group A) were not administered any other intravenous or oral antibiotics. Other medications were permitted depending upon the clinical condition of subjects and need for such medication like analgesics and proton pump inhibitors.

Febrile morbidity was defined as oral temperature 100.4 F or higher on 2 separate occasions 24 hrs apart exclusive of first $24 \mathrm{hrs}$ following surgery. The wound was inspected on the day of suture removal with few exceptions like soakage from wound, persistent high fever or marked tenderness over the operated site. Endometritis was diagnosed in patients with febrile morbidity, tachycardia, foul smelling lochia and uterine tenderness with or without positive high vaginal swab culture.

Wound was further classified into following groups:

1. Satisfactory healing - no wound discharge or erythema

2. Wound infection - purulent exudates with erythema but no separation of deep tissue-managed by regular dressing

3. Wound dehiscence - separation of deep tissue with purulent exudates managed by regular dressing followed by secondary suture.

Adverse events, reported spontaneously by the subject or noted by the doctor were noted in the case report form.

On an individual subject the study was terminated in the following circumstances:

1. Development of complication requiring treatment with additional antibiotic.

2. Inadvertent use of antibiotic by any attending doctor.

Data were collected on pre-designed case report form and analysed for significant difference between the two groups through non parametric test and Mann-Whitney U test. Adverse event data was analysed by Chi square or Fisher's exact test as appropriate.

Graphpad Instat 3 McIntosh, California, software was used for analysis.

\section{RESULTS}

A total of 300 subjects were recruited for study, 150 in group A and 150 in group B were compared in the study. 
Baseline characteristics like age, parity, gestational age, and duration of labour are comparable in both the groups (Table 1). In both the groups, previous history of CD was the main indication. Other indications are shown in table 2 .

Table 1: Baseline characteristics of the patient.

\begin{tabular}{|lcll|}
\hline Group & A & B & P \\
\hline Age (Mean+SD) (Years) & & \\
\hline Elective & $25.37 \pm 2.59$ & $23 \pm 5.38$ & 0.033 \\
\hline Emergency & $25.59 \pm 2.9$ & $25.15 \pm 4.46$ & 0.371 \\
\hline Parity & & \\
\hline Elective & $2.26 \pm .85$ & $1.68 \pm .95$ & 0.027 \\
\hline Emergency & $1.89 \pm .63$ & $1.95 \pm .91$ & .507 \\
\hline Gestational age (Weeks) & & \\
\hline Elective & $37.86 \pm .55$ & $37.84 \pm .69$ & 0.93 \\
\hline Emergency & $38.26 \pm .79$ & $38.21 \pm .76$ & .632 \\
\hline Labor duration (Hour) & & \\
\hline Elective & $6.09 \pm 1.44$ & $5.05 \pm 1.54$ & 0.018 \\
\hline Emergency & $5.63 \pm 1.23$ & $5.13 \pm .75$ & 0.000 \\
\hline
\end{tabular}

Elective: Group A $(\mathrm{n}=35)$, Group B ( $\mathrm{n}=19)$; Emergency: Group A $(n=115)$, Group B $(n=131)$.

Table 2: Indication of caesarean section.

\begin{tabular}{|l|l|l|}
\hline Caesarean section & A & B \\
\hline 2 previous CD & 11 & 0 \\
\hline BOH & 1 & 0 \\
\hline breech & 4 & 2 \\
\hline CPD & 0 & 5 \\
\hline FD & 0 & 4 \\
\hline h/o rectopexy & 1 & 0 \\
\hline IUGR & 0 & 1 \\
\hline Oligohydramnios & 1 & 2 \\
\hline Precious pregnancy & 0 & 1 \\
\hline previous CD & 17 & 4 \\
\hline Emergency & & \\
\hline Caesarean section & A & B \\
\hline 2 previous CD & 3 & 6 \\
\hline Breech & 5 & 6 \\
\hline CPD & 14 & 18 \\
\hline Face presentation & 0 & 1 \\
\hline Fetal distress & 4 & 42 \\
\hline IUGR & 5 & 1 \\
\hline Maternal genital warts & 1 & 0 \\
\hline Oligohydramnios & 6 & 6 \\
\hline Precious pregnancy & 6 & 1 \\
\hline Previous CD & 67 & 50 \\
\hline & & \\
\hline
\end{tabular}

Following single dose prophylactic antibiotic therapy, the incidence of fever, mild or moderate wound infection did not differ significantly in both groups (Table 3). Among elective $\mathrm{CD}$, one patient in group $\mathrm{A}$ and no patients in group B developed fever. Again among emergency CD 3 and 4 patients developed fever in group I and group II, respectively, and neither result was statistically significant ( $\mathrm{p}=0.45$ and 0.83 ). There was no incidence of endometritis or any serious infection. Fever subsided after oral paracetamol tablet and no antibiotic therapy required. There were no adverse reactions to any of the antibiotics.

Table 3: Outcome measures.

\begin{tabular}{|c|c|c|c|c|}
\hline & $\mathbf{A}$ & B & $\mathbf{P}$ & $\begin{array}{l}\mathbf{R R} \\
(95 \% \mathrm{CI})\end{array}$ \\
\hline \multicolumn{5}{|c|}{ Febrile Illness } \\
\hline Elective & 1 & 0 & 0.457 & $\begin{array}{l}0.642 \\
(0.525- \\
0.785)\end{array}$ \\
\hline Emergency & 3 & 4 & 0.834 & $\begin{array}{l}1.176 \\
(0.258- \\
5.367)\end{array}$ \\
\hline \multicolumn{5}{|l|}{ UTI } \\
\hline Elective & - & - & - & \\
\hline Emergency & 0 & 3 & 0.103 & $\begin{array}{l}0.527 \\
(0.468- \\
0.593)\end{array}$ \\
\hline \multicolumn{5}{|c|}{ Minor Wound infection } \\
\hline Elective & - & - & - & \\
\hline Emergency & 2 & 4 & 0.505 & $\begin{array}{l}1.78 \\
(0.32-9.9)\end{array}$ \\
\hline \multicolumn{5}{|c|}{ Moderate Wound infection } \\
\hline Elective & - & - & - & \\
\hline Emergency & 1 & 2 & 0.639 & $\begin{array}{l}1.767 \\
(0.158- \\
19.750)\end{array}$ \\
\hline
\end{tabular}

Elective: Group A ( $\mathrm{n}=35)$, Group B ( $\mathrm{n}=19)$; Emergency: Group A $(n=115)$, Group B $(n=131)$.

\section{DISCUSSION}

Any antibiotic is effective in clean and uncontaminated cases and choice should therefore be based on other factors such as cost. ${ }^{9}$ We desired to determine whether comparatively narrow spectrum low cost cephalosporinecefotaxime with more expensive commonly used triple drug regimen and we found that narrow spectrum cefotaxime was as effective as triple drug regimen.

For most surgical procedure, it is desirable to administer prophylactic antibiotic pre-operatively before tissue injury and bacterial contamination occur. If this policy were implemented for $\mathrm{CD}$, the neonate would be exposed to antibiotic before birth. In theory even this limited exposure might interfere with the ability of the pediatrician to evaluate the newborn for sepsis. ${ }^{10}$ However, Thigpen et al. have concluded that there was no difference in maternal infectious morbidity whether antibiotics were given before skin incision or after cord clamping. ${ }^{11}$

Numerous antibiotics have been used in studies evaluating prophylaxis in patients undergoing $\mathrm{CD}$ the most frequently used agent include penicillins and 
cephalosporins. Most studies have shown a significant difference between these antibiotics and placebo but no significant difference between various antibiotics used for prophylaxis. So the ideal choice of an antibiotic has not yet been defined. Similarly Parulekar et al. concluded that prophylactic single dose cefotaxime is more effective as compared to conventional 5 days gentamycin-cloxacillin combina-tion. $^{12}$ Newer more expensive and broader spectrum cephalosporin had no extra beneficial effect than less expensive cefazoline. ${ }^{11}$ Single dose cefazoline prophylaxis appears to be comparable to multidose prophylaxis in reducing febrile morbidity after $\mathrm{CD} .^{7,13}$ Again, Noyes et al. studied the incidence of postpartum endomyometritis following single dose antibiotic prophylaxis with either ampicillin/sulbactum, cefazoline or cefotetan and they concluded that no statistical significant difference of infection rate..$^{13}$

We have not followed the patient for further any infection related morbidity after their hospital discharge.

\section{CONCLUSION}

Both triple drug regimen and single dose cefotaxime have similar efficacy in reducing maternal postoperative infectious morbidity. So less costly cefotaxime should be preferred compared to more costly triple drug regimen combination.

Funding: No funding sources

Conflict of interest: None declared

Ethical approval: The study was approved by the Institutional Ethics Committee

\section{REFERENCES}

1. Wild SM. Antibiotic prophylaxis at caesarean section. The Lan-cet. 2002;360:724.

2. Rouzi AA, Khalifa F, Ba'aqeel H. The routine use of ce-fazoline in cesarean section. Int J Obst Gynecol. 2000;69:107-12.

3. Chelmow D, Ruheli MS, Huang E. Prophylactic use of antibiotics for nonlaboring patients undergoing cesarean delivery with intact membranes: a meta analysis. Am J Obstet Gynecol. 2001;184:656-61.
4. Mah MW, Pyper AM, Oni GA, et al. Impact of antibiotic pro-phylaxis on wound infection after cesarean section in a situation of expected higher risk. Am J Infec Control. 2001;29:85-8.

5. Smaill F, Hofmeyr GJ. Antibiotic prophylaxis for cesarean sec-tion. The Cochrane Database Syst Rev. 2002;3:CD000933.

6. Smaill F, Hofmeyr GJ. Antibiotic prophylaxis for cesarean sec-tion. Oxford: The Cochrane Library; 2007. p. 4.

7. Hopkins L, Smaill F. Antibiotic prophylaxis regimens and drugs for cesarean section. Cochrane Database Syst Rev. 1999;CD 001136.

8. Shah S, Mazher Y, John S. Single or triple dose piperacillin prophylaxis in elective cesarean section. Int J Obstet Gynecol. 1998;62:23-9.

9. Alekwe LO, Kuti O, Orji EO. Comparison of ceftriaxone verses triple drug regimen in the prevention of caesarean section infectious morbidities. J Matern Fetal Neonatal Med. 2008;21:638-42.

10. Shetty J, Vyas NM, Kumar P. Antibiotic prophylaxis for hysterectomy and caesarean section: Amoxycillin-clavulanic acid versus cefazolin. J Obstet Gynecol Ind. 2010;60:419-23.

11. Thigpen BD, Hood WA, Chauhan S, et al. Timing of prophylactic antibiotic administration in the uninfected laboring gravida: a randomized clinical trial. Am J Obstet Gynecol. 2005;192:1864-71.

12. Parulekar P, Kumar S, Awasthi RT, et al. A single dose of cef-otaxime: as a prophylaxis during cesarean section. J obstet Gynecol Ind. 2001;51:11821.

13. Noyes N, Berkley As, Freedman K, et al. Incidence of postpartum endomyometritis following single dose antibiotic prophylaxis with either ampicillin/sulbactum, cefazoline or cefotetan in high risk cesarean section patients. Infect Dis Obstet Gynecol. 1998;6:220-3.

Cite this article as: Prathima S, Savitha C, Tejeswini KK, Anitha GS. Comparative study of single dose versus multiple doses of antibiotic prophylaxis in caesarean delivery. Int J Reprod Contracept Obstet Gynecol 2017;6:215-8. 